\title{
Investigation of Empathy Skills and Moral Decision-Making Attitudes in Athlete Students in Terms of Some Variables
}

\author{
Serhat Turan (Corresponding author) \\ Sports Science Faculty, Balıkesir University, Balıkesir, Turkey \\ Tel: 90-507-664-6639 E-mail: serhat.turan@balikesir.edu.tr \\ Ercan Çirmi \\ Sports Science Faculty, Balıkesir University, Balıkesir, Turkey \\ Tel: 90-505-399-7465 E-mail: cirmiercan@gmail.com
}

Received: October 7, $2021 \quad$ Accepted: November 11, 2021

Published: December 1, 2021

doi:10.5296/jei.v7i2.19072ＵRL: https://doi.org/10.5296/jei.v7i2.19072

\begin{abstract}
It is observed that the appearance of aggression and violent anti-social behavior in sports contradicts the Olimpia culture inherent in sports. Therefore, this research was conducted in order to reveal the causes and consequences of negative behaviors observed in sports, to examine the empathy skills and moral decision-making attitudes of athletes in terms of different variables. The research was arranged by the screening survey model. A total of 319 athletes, 180 men, and 139 women, engaged in individual and team sports in the city where the research was conducted, voluntarily participated in this research. Personal information form, "Prediction in Sports and Empathy in Sports" and "Attitudes to Moral Decision-making in Youth Sport Questionnaire" were applied to the participants. In the analysis of the data, the Manova test and the LSD test were used to determine the source of the difference. As a result of the research, while a significant difference was found in favor of men in terms of gender in empathy skills $(\mathrm{p}<.05)$; there was not found a significant difference in terms of sports branch and sports year $(\mathrm{p}>.05)$. In terms of the sports year variable, the moral decision-making attitude scores of individuals who have just started sports (0-2 years) compared to individuals who have been doing sports for a long time(9+ years) were found to be higher and this result was found to indicate a statistically significant difference $(\mathrm{p}<.05)$. There was not found a
\end{abstract}


significant difference in moral decision-making attitudes scores in terms of sports year and gender.

Keywords: Sports, Empathy, Moral-decision making

\section{Introduction}

It is seen that aggression and violent behaviors emerge in athletes with the ambition to win brought by the competitive and success factor inherent in sports (Bull, 1991; Yücel, Atalay, \& Gürkan, 2015).

Morality is the shape of the distinction between good and bad behavior (Ministry of Education, 2013). Many developmental scientists agree that morality is not only related to the individual but also their behaviors and actions towards others (Killen \& Smetana, 2015). For this reason, it can be said that racism, aggressive attitude, violent acts, and behaviors experienced in today's sports environment are directly related to the moral attitude of the individual.

In sports competitions, the competitive environment and ambition to win, which are evident in today's conditions, make the action and moral attitude of the individual more visible (F. Ö. Kuter \& M. Kuter, 2012). Moral attitude in sports, as well as abiding by the rules of the game; also refers to love, respect, honesty, helpfulness, sacrifice, and fair play towards teammates and opponents. It is observed that individuals who internalize moral attitude behaviors in sports reflect these values to their social lives (Popescu \& Masari, 2011).

Individuals may encounter different situations in the sports environment. In the face of these situations, the individual enters the decision-making process with a moral attitude. Moral decision-making means that the individual chooses the right thing as a result of his moral values (Daştan, Bellikli, \& Bayraktar, 2015).

In the sports environment, it has been stated that the motivational levels of the athletes have a significant relationship with the moral decision-making process, and the motivational climate initiated by the trainers on the athletes (Wagnsson, Stenling, Gustafsson, \& Augustsson, 2016), has a significant relationship between basic psychological satisfaction and moral decision making, and it has been reported that athletes with high levels psychological satisfaction have a positive contribution to moral decision-making (Hodge \& Gucciardi, 2015). In terms of the parental style model and its relationship with the moral decision-making process, athletes with authoritarian parents behave more carefully in making moral decisions than athletes without authoritarian parents (Yaffe, Levental, Arey, \& Lev, 2021), it was observed that moral-decision making processes were negatively affected by athletes having egocentric thinking in terms of egocentric thinking and moral-decision making process (Shrout, Voelker, Munro, \& Kubitz, 2016).

In the sports environment, the moral decision-making attitude of the individual can manifest itself with positive behaviors and actions towards their competitors and friends. Although these positive behaviors and actions are directly related to the empathy skills of the individual; it is said that empathy anxiety prevents anti-social behaviors (Feshbach \& Feshbach, 1986; Kavussanu, Ring, \& Kavanagh, 2014). As a matter of fact, Kavussanu et al.'s (2009) research 
on male and female athletes aged 15-47 in 2009 revealed that individuals with high empathy skills avoid exhibiting anti-social behaviors that are common in the sports environment.

Empathy is generally expressed in two ways as "cognitive empathy" and "emotional empathy". The individual's understanding of the "feelings and thoughts" of the other person, for example; Just as the conclusion that someone is sad is "cognitive empathy", the individual experiences the "feelings" of the other person, for example; Just as when someone is sad, the state of being sad with him is defined as "emotional empathy" (Bloom, 2017). For this reason, it becomes an undeniable fact that the development of empathy skills of the individual not only contributes positively to the social life of the society but is also needed in the sports environment.

It is observed that individuals with high empathy skills have lower violent and aggressive behaviors in the sports environment (Kavussanu, Stamp, Slade, \& Ring, 2009). However, some trainers focus on success along with the ambition to win. For this reason, it is thought that the increase of anxiety levels for their teammates and rival players together with the development of empathy skills of athletes will create a mental and physical performance deficiency on their athletes (Shields \& Bredemeier, 1994; Sezen, Balçikanli, \& Sezen, 2017).

It is stated that the individual develops his communication and empathy skills with the training programs applied for the development of physical, cognitive, and sensory skills in the sports environment and that the individual exhibits positive behaviors in the social environment with the development of these skills (Hermens, Super, Verkooijen, \& Koelen, 2017).

It is a fact that individuals participating in sports are exposed to racism, aggressive attitude, and violent behaviors, especially in today's sports environment, by their teammates or rival team athletes, which damage the concept of "moral person" intended in the sports environment. It is thought that one of the factors that will enable individuals to have morality is sports. For this reason, it is aimed to determine the moral decision-making attitudes and empathy skills of athlete students studying at the high school level. Thus, it will be understood to what extent participating in sports affects on moral decision-making attitude and empathy.

\section{Method}

\subsection{Research Method}

This research, which examines the empathy skills and moral decision-making attitudes of high school students in the sports environment in terms of some variables, is in the screening survey model. Screening survey models are expressed as research approaches that aim to describe a past or present situation as it exists. In this model, the individual or object subject to the research is tried to be defined within its conditions, it is addressed as it exists and the opinions of the participants or interests, skills, attitudes, etc. features are tried to be determined (Karasar, 2019). 


\subsection{Research Group}

The research group of the research consists of students studying in-state high schools in the 2020-2021 academic year. The research group was determined using the simple random sampling method. In this sampling method, all units have an equal and independent chance to be selected as sampling (Büyüköztürk et al., 2013). 319 high school students (male age = $16.05 \pm 2.08$, female age $=15.13 \pm 2.02$ ) participated in the research. Within the scope of the research, a questionnaire was distributed to 349 high school students and after the missing or incorrectly filled questionnaires were removed, the research was carried out with the data of the remaining 319 students. The legal permission was obtained from the Social Sciences and Humanities Ethics Committee of Balıkesir University for the application of the research. Voluntary participation was taken as a basis in the execution of the application. The measurement tools described in the data collection tools section were applied to the students.

Table 1. Descriptive statistical information

\begin{tabular}{|l|l|l|l|}
\hline \multirow{3}{*}{ Gender } & & Frequency & Percent \\
\hline \multirow{3}{*}{ Sports } & Male & 178 & 55.8 \\
\cline { 2 - 4 } & Female & 141 & 44. \\
\hline \multirow{5}{*}{ Sports year } & Individual & 157 & 49.2 \\
\cline { 2 - 5 } & Team & 162 & 50.8 \\
\hline & $0-2$ years & 41 & 12.9 \\
\cline { 2 - 5 } & $3-5$ years & 78 & 24.5 \\
\cline { 2 - 5 } & $6-8$ years & 81 & 25.4 \\
\cline { 2 - 4 } & 9 years and above & 119 & 37.3 \\
\hline & Total & 319 & 100.0 \\
\hline
\end{tabular}

\subsection{Data Collection Tools}

In the collection of research data, "Personal Information Form", "Prediction in Sports and Empathy in Sports" and "Attitudes to Moral Decision-making in Youth Sport Questionnaire" were used.

\subsubsection{Personal Information Form}

In the personal information form created by the researcher based on the literature; There are age, gender, sports branch (team sports and individual sports), and sports year information.

\subsubsection{Prediction in Sports and Empathy in Sports}

In this research, "Prediction in Sports and Empathy in Sports" developed by Erkuş and 
Yakupoğlu (2001) was used to determine the emphatic skill levels of athletes. The four-category Likert-type scale consisting of 32 items related to the emotional and cognitive aspects of empathy in the sports environment was applied to 278 athletes in the first trial application and the non-working items were removed as a result of the analyzes and reduced to 19 items. The second trial application was carried out on 242 athletes and as a result of the analysis, the final scale consisting of 2 factors (Prediction in Sports and Emotional Empathy in Sports) was created. The reliability of the scale is stated as 0.789; is at an acceptable level.

\subsubsection{Attitudes to Moral Decision-making in Youth Sport Questionnaire}

The "Attitudes to Moral Decision-making in Youth Questionnaire" developed by Lee, Whitehead, and Ntoumanis (2007) to measure the moral decision-making attitudes of athletes, and Gürpınar (2014) conducted a Turkish validity and reliability to collect data in the research was used. In the research, the Cronbach Alpha coefficient of the scale was 0.76, and the test-retest reliability coefficient was 0.855 . The original scale is a 5-point Likert-type scale with 9 items and 3 sub-dimensions and scored between strongly disagree (1) and strongly agree (5). The sub-dimensions of the scale are to adopt a love of competition, to adopt cheating, and to protect fair winning. It is factored to measure moral decision-making attitudes. All of the items on the scale have a negative meaning. Higher scores on the scale mean that athletes are more likely to differ from morality. The reliability analysis of the scales used in the research is presented in Table 2.

Table 2. Values for the scales

\begin{tabular}{|l|l|l|l|l|}
\hline Scales & $\mathbf{N}$ & Cronbach's Alpha & Mean & SD \\
\hline SEM & 16 & .87 & 3.54 & .36 \\
\hline AMDYSQ & 9 & .70 & 4.20 & .55 \\
\hline
\end{tabular}

Note. SEM: Empathy in Sports Environment; AMDYSQ: Attitudes to Moral Decision-making in Youth Questionnaire.

\subsection{Analysis of Data}

The SPSS 25 package program was used to analyze the data in the research. While the frequency and percentage analysis were used to determine the descriptive characteristics of the students participating in the research, the arithmetic mean and standard deviation analyzes were used to determine the attitude levels of empathy and moral decision-making in the sports environment. Empathy and moral decision-making attitude levels in sports in terms of gender (male and female), sports branch (individual sports and team sports), and sports year (0-2 years, 3-5 years, 6-8 years, and 9 years and above) variables Manova analysis was carried out to determine whether it differs or not. The homogeneity of covariance matrices and variances were tested and according to the analysis result, it was determined that the covariance matrices were homogeneous $(\mathrm{F}=1.106, \mathrm{p}>.05)$. For this reason, Wilks' Lambda 
values were taken into consideration. In order to determine the source of the differences, the LSD test, which is one of the post hoc tests used when the variance distribution is homogeneous, was used. The level of significance in the research was determined as $p<.05$.

\section{Results}

The results of the analyzes conducted in order to determine the high school students' level of empathy in the sports environment and the moral decision-making attitude in sports and the differences between the groups are given below.

Manova analysis was conducted to examine the total scores of SEM and AMDYSQ scales in the research. SEM and AMDYSQ total scores were entered as the dependent variable to the model. The variables of gender (female, male), sports branch (team sport, individual sports), and sports year (0-2 years, 3-5 years, 6-8 years, 9 years and above) were entered as independent variables to the model.

As a result of Manova analysis, gender*sports branch*sports year main effect (Wilks' Lambda $\left.=.964, \mathrm{~F}_{(6,604)}=1.869, \mathrm{p}=.084, \eta^{2}=.018\right)$ sports branch*sports year main effect (Wilks' Lambda $=.977, \mathrm{~F}_{(6,604)}=1.175, \mathrm{p}=.318, \eta^{2}=.012$ ), gender*sports year main effect (Wilks' Lambda $=.974, \mathrm{~F}_{(6,604)}=1.328, \mathrm{p}=.242, \eta^{2}=.013$ ), gender* sports branch main effect (Wilks' Lambda $=.999, \mathrm{~F}_{(2,302)}=.186, \mathrm{p}=.830, \eta^{2}=.001$ ) and sports branch main effect (Wilks' Lambda $=.997, \mathrm{~F}_{(2,302)}=.502, \mathrm{p}=.606, \eta^{2}=.003$ ) was not found significant. Gender main effect (Wilks' Lambda $=.962, \mathrm{~F}_{(2,302)}=5.920, \mathrm{p}=.003, \eta^{2}=.038$ ) and sports year main effect (Wilks' Lambda $=.946, \mathrm{~F}_{(6,604)}=2.817, \mathrm{p}=.010, \eta^{2}=.027$ ) were significant. A follow-up test was conducted on the main effects of sports branch, gender and sports year variables, and the results are presented in Table 3.

Table 3. SEM and AMDYSQ Follow-up test for sports branch, gender and sports year variables

\begin{tabular}{|c|c|c|c|c|c|c|c|c|}
\hline Source & \multicolumn{2}{|c|}{ Dependent Variable } & Mean & SD & $\mathbf{F}$ & Sig. & $\eta^{2}$ & LSD \\
\hline \multirow{2}{*}{ Sport Branch } & \multicolumn{2}{|l|}{ SEM } & 3.54 & .37 & .004 & .951 & .000 & \\
\hline & \multicolumn{2}{|l|}{ AMDYSQ } & 4.20 & .55 & 1.004 & .317 & .003 & \\
\hline \multirow{3}{*}{ Gender } & \multirow{2}{*}{ SEM } & Male & 3.55 & .37 & \multirow{2}{*}{11.692} & \multirow{2}{*}{$.001 *$} & \multirow{2}{*}{.037} & \\
\hline & & Female & 3.51 & .36 & & & & \\
\hline & \multicolumn{2}{|l|}{ AMDYSQ } & 4.20 & .55 & .000 & .993 & .000 & \\
\hline \multirow{5}{*}{ Sport Year } & SEM & & 3.54 & .37 & .085 & .968 & .001 & \multirow{5}{*}{$1>4$} \\
\hline & \multirow{4}{*}{ AMDYSQ } & $0-2$ years & 4.33 & .60 & & \multirow{4}{*}{$.001 *$} & \multirow{4}{*}{.051} & \\
\hline & & $3-5$ years & 4.25 & .50 & & & & \\
\hline & & $6-8$ years & 4.17 & .50 & & & & \\
\hline & & +9 & 4.11 & .58 & & & & \\
\hline
\end{tabular}

Note. ${ }^{*} \mathrm{p}<.05$; SEM: Empathy in Sports Environment; AMDYSQ: Attitudes to Moral Decision-making in Youth Questionnaire; $0-2=1,3-5=2,6-8=3 ;+9=4$. 
As a result of the Manova follow-up test performed in Table 3, it was determined that there is a significant difference in the SEM averages of female and male students $(F=11.692, p<.05$, $\left.\eta^{2}=.037\right)$. When the averages obtained from the SEM scale were evaluated, it was determined that the scores of the male students (Mean $=3.55, \mathrm{SD}=.37$ ) were significantly different from the scores of the female students (Mean $=3.51, \mathrm{SD}=.36)$. In addition, it has been determined that gender explains $3.7 \%$ of the empathy behavior in the sports environment. As the AMDYSQ scale was found to be significant in the sports year variable, LSD test was applied from multiple comparison tests, and the average scores of individuals who did sports for $0-2$ years $($ Mean $=4.33, \mathrm{SS}=.60)$ were found to be significantly higher than the average scores of individuals who did sports +9 years (Mean $=4.11, \mathrm{SS}=.55)$. It has been determined that the sports year variable explains 5.4\% of AMDYSQ.

\section{Discussion}

With this research, empathy skills and moral decision-making attitudes of athletes were examined in terms of some variables (gender, sports year, and sports branch).

Depending on the gender variable, the empathy skill averages of males were found to be higher than that of females, and this change was found to be statistically significant. When looking at the literature, Murray (1998) found that females were more successful than males in terms of empathy skills in his research, but; he stated that males can be as successful in empathy as females as a result of supporting their empathy skills with necessary education (Murray, 1998; Özbek, 2015). Again, Cotton (2001) found that empathy skills make a statistically significant difference according to the age variable and this difference is in favor of individuals with advanced age. In this sense, it can be said that the empathy skill score in the research is in favor of males, due to the result that the average age of male athletes is higher than the average age of female athletes. Yiğiter (2008) stated in his research that the empathy skill scores of males are higher than females. The stated result is similar to this research. Garcia, Lopez, and Gutierrez (2015) stated in their research that gender factor does not make a significant difference on empathic tendency; according to some researches in the literature, it has been revealed that empathy skill scores show a significant difference in favor of females in terms of gender (Toussaint \& Webb, 2005; Turnage et al., 2012; Carlo et al., 2003; Hojat et al., 2014; Rueckert \& Naybar, 2008). The results stated in this sense differ from the results of this research.

There was not found a statistically significant difference in the empathy skills of the sports year variable in the research. When we review at the literature, while our research results are similar to some researches (Karabulut \& Bahadır, 2013; Mutlu et al., 2014; Topçu, 2019), there are also results indicating that there is a significant difference between the sports year and empathy skills in different researches (Erkmen, 2017; Elik, 2017; Ayaş \& Çoban, 2018).

According to this research, it was concluded that empathy skills did not show a statistically significant difference in terms of sports branch. When the literature is examined, some researches show similar results with this research (Laborde et al., 2014; Kajbafnezhad et al., 2012; Batinic et al., 2014), there are also researches in the literature stating that the empathy skill scores of individuals who are engaged in team sports are higher than those who are 
engaged in individual sports and that reveal different results with these research results (Akelaitis et al., 2018; Soflu et al., 2011; Singh \& Mili, 2015).

There was not found a statistically significant difference in terms of moral decision-making attitudes among individuals engaged in sports, depending on the gender variable in the research. Arslan (2018) revealed similar results to our research in his research. In some researches, it was stated that female athletes' moral decision-making attitude scores were higher than male athletes (Lee et al., 2007; Koul, 2012; Ponseti et al., 2012; Turan, 2020).

According to the results of the research, when the moral decision-making attitude was examined in terms of the sports year variable, the scores of the individuals who started sports (0-2 years) were found to be higher than the individuals who did sports for 9 years or longer, and it has been determined that this result also creates a statistically significant difference. The reason for this can be stated as the increase in the anxiety of gaining financial gain by individuals who have been in the sports environment for a long time, and the feeling of struggle and ambition prevents the individual's self-control mechanism. Görgülü et al. (2018) stated in their research that with the industrialization of sports, the phenomenon of winning-losing evolved into an all-or-nothing feeling, and as a result, anti-social and anti-sports behaviors emerged. In some studies in the literature, it has been observed that the moral decision-making attitudes of individuals who have just started sports are higher than those who have been engaged in sports for a long time, and this result is statistically significant (Lee et al., 2007; Coulomb-Cabagno \& Rascle, 2006). These results are similar to the research conducted. In different researches, it was stated that there was no significant difference between the sports year variable and the moral decision-making attitude (Arslan, 2018; Sağın \& Akbuga, 2019).

According to the sports branch variable, there was no significant difference between individuals engaged in team sports and individual sports in terms of moral decision-making attitudes. Lee et al. (2007) stated in their research that the moral attitude scores of individuals who are engaged in team sports are lower than those who are interested in individual sports. Again, when the literature is reviewed, it was observed that the athletes who are interested in sports branches with a high level of combat and physical contact have low moral decision-making attitudes (Tucker \& Parks, 2001; Mouratidou, Chatzopoulos, \& Karamavrou, 2007). According to some researches, empathy skills were examined according to different branches of team sports and it was stated that athletes interested in volleyball attach more importance to sportive values than basketball (Tsai \& Fung, 2005). The results of the researches mentioned and the results of this research differ.

\section{Conclusion}

According to these results, the empathic tendencies of athletic individuals; There was no statistically significant difference in terms of sports year and sports branch variable, but it was concluded that there was a significant difference in terms of gender variable; In the moral decision-making dimension, it was determined that only the sports year variable made a significant difference. 


\section{References}

Akelaitis, A. V., \& Malinauskas, R. K. (2018). The expression of emotional skills among individual and team sports male athletes. Pedagogics, Psychology, Medical-Biological Problems of Physical Training and Sports, 2. https://doi.org/10.15561/18189172.2018.0201

Arslan, B. (2018). Türkiye'deki bocce ve dart sporcularının ahlaki karar alma tutumlarının incelenmesi (Master's thesis, Bartın Üniversitesi, Eğitim Bilimleri Enstitüsü).

Ayaş, B. E., \& Çoban, B. (2018). Bireysel Spor Branşı İle İlgilenen Sporcuların Empatik Eğilim Düzeylerini İncelenmesi. Türk \& Íslam Dünyası Sosyal Araştırmalar Dergisi, 5(16), 420-429. https://doi.org/10.16989/TIDSAD.1249

Batinic, T. S., Svaic, V., \& Babic, J. (2014). Differences in emotional competence between individual and team sports athletes. Proceedings of the 7th international scientific conference on kinesiology: Fundamental and applied kinesiology (pp. 552-555). Faculty of Kinesiology Zagreb, University of Zagreb, Opatija, Croatia.

Bloom, P. (2017). Empathy and Its Discontents. Trends in Cognitive Sciences, 21(1), 24-31. https://doi.org/10.1016/j.tics.2016.11.004

Büyüköztürk, Ş., Kılıç Çakmak, E., Akgün, Ö. A., Karadeniz, Ş., \& Demirel, F. (2013). Bilimsel araştırma yöntemleri. Pegem Akademi Yayıncılık.

Carlo, G., Hausmann, A., Christiansen, S., \& Randall, B. A. (2003). Sociocognitive and behavioral correlates of a measure of prosocial tendencies for adolescents. The Journal of Early Adolescence, 23(1), 107-134. https://doi.org/10.1177/0272431602239132

Cotton, K. (2001). Developing, Empathy in Children and Youth. School Improvement Research Series. Retrieved from https://www.lyrics.com

Coulomb-Cabagno, G., \& Rascle, O. (2006). Team sports players' observed aggression as a function of gender, competitive level, and sport type. Journal of Applied Social Psychology, 36(8), 1980-2000. https://doi.org/10.1111/j.0021-9029.2006.00090.x

Daştan, A., Bellikli, U., \& Bayraktar, Y. (2015). Muhasebe Etik İkilem ve Etik Karar alma Konularına yönelik KTÜ-İ̈BF Öğrencileri Üzerine Bir Araştırma. Ekonomik ve Sosyal Araştırmalar Dergisi, 11(1), 75-92.

Elik, T. (2017). Güneydoğu Anadolu Bölgesi Futbol Takımlarında Amatör Olarak Futbol Oynayan Sporcuların Sportmenlik Yönelimleri ve Empatik Ĕ̆ilim Düzeyleri (Yüksek Lisans Tezi, T.C. İstanbul Gelişim Üniversitesi, Sağlık Bilimleri Enstitüsü, Antrenörlük Eğitimi Anabilim Dalı Hareket Ve Antrenman Bilimleri Bilim Dalı, İstanbul).

Erkmen, G. (2017). Selçuk Üniversitesi Beden Eğitimi Ve Spor Yüksekokulunda Öğrenim Gören Öğrencilerin Empatik Eğilimlerinin Sporda Tercih Ettikleri Lider Davranışları İle Karşılaştırılması (Yüksek Lisans Tezi, T.C. Selçuk Üniversitesi Sağlık Bilimleri Enstitüsü Beden Eğitimi ve Spor Öğretmenliği Anabilim Dalı, Konya).

Erkuş, A., \& Yakupoglu, P. (2001). An empathy scale (SEM) Development Study in a sports 
environment. Journal of Sports Science, 12(1), 22-31.

García-López, L. M., \& Gutiérrez, D. (2015). The effects of a sport education season on empathy and assertiveness. Physical Education and Sport Pedagogy, 20(1), 1-16. https://doi.org/10.1080/17408989.2013.780592

Görgülü, R., Adiloğulları, G. E., Tosun, Ö. M., \& Adiloğulları, İ. (2018). Prososyal Ve Antisosyal Davraniş İle Sporcu Kimliğinin Bazi Değişkenlere Göre İncelenmesi. Spor ve Performans Araştırmaları Dergisi, 9(3), 147-161. https://doi.org/10.17155/omuspd.397248

Gürpınar, B. (20114). Adaptation of the scale of moral decision-making attitudes in infrastructure sports to Turkish culture: a study of validity and reliability in a Turkish sample. Education and Science, 39(176). https://doi.org/10.15390/EB.2014.3643

Hermens, N., Super, S., Verkooijen, K. T., \& Koelen, M. A. (2017). A Systematic Review of Life Skill Development through Sports Programs Serving Socially Vulnerable Youth. Research Quarterly for Exercise and Sport, 88(4), 408-424. https://doi.org/10.1080/02701367. 2017.1355527

Hodge, K., \& Gucciardi, D. F. (2015). Antisocial and Prosocial Behavior in Sport: The Role of Motivational Climate, Basic Psychological Needs, and Moral Disengagement. Journal of Sport and Exercise Psychology, 37(3), 257-273. https://doi.org/10.1123/jsep.2014-0225

Hojat, M., Gonnella, J. S., Nasca, T. J., Mangione, S., Vergare, M., \& Magee, M. (2014). Physician Empathy: Definition, Components, Measurement, and Relationship to Gender and Specialty. Am J Psychiatry, 159(9), 1563-1569. https://doi.org/10.1176/appi.ajp.159.9.1563

Kajbafnezhad, H., Ahadi, H., Heidarie, A., Askari, P., \& Enayati, M. (2012). Predicting athletic success motivation using mental skills and emotional intelligence and its components in male athletes. Journal of Sports Medicine and Physical Fitness, 52, 551-557.

Karabulut, O. E., \& Bahadır, Z. (2013). Ümit Milli Judo Takımının Olumsuz Değerlendirilmekten Korkma ve Empatik Eğilim Düzeylerinin İncelenmesi. Niğde Üniversitesi Beden Ĕ̌itimi Ve Spor Bilimleri Dergisi, 7(2).

Karasar, N. (2019). Bilimsel araştırma yöntemi. Nobel Yayın Dağıtım.

Kavussanu, M., Ring, C., \& Kavanagh, J. (2014). Antisocial Behavior, Moral Disengagement, Empathy and Negative Emotion: A Comparison between Disabled and Able-Bodied Athletes. Ethics \& Behavior, 25(4), 297-306. https://doi.org/10.1080/10508422.2014.930350

Kavussanu, M., Stamp, R., Slade, G., \& Ring, C. (2009). Observed Prosocial and Antisocial Behaviors in Male and Female Soccer Players. Journal of Applied Sport Psychology, 21(1), 62-S76. https://doi.org/10.1080/10413200802624292

Killen, M., \& Smetana, J. G. (2015). Origins and Development of Morality. Handbook of Child. Psychology and Developmental Science, 3(17), 1-49. https://doi.org/10.1002/97811189 63418.childpsy317

Koul, R. (2012). Multiple motivational goals, values, and willingness to cheat. International 
Journal of Educational Research, 56, 1-9. https://doi.org/10.1016/j.ijer.2012.10.002

Kuter, F. Ö., \& Kuter, M. (2012). Beden eğitimi ve spor yoluyla değerler eğitimi. Journal of Education and Humanities: Theory and Practice, 3(6), 75-94.

Laborde, S., Dosseville, F., Guillén, F., \& Chávez, E. (2014). Validity of the trait emotional intelligence questionnaire in sports and its links with performance satisfaction. Psychology of Sport and Exercise, 15, 481-490. https://doi.org/10.1016/j.psychsport.2014.05.001

Lee, M. J., Whitehead, J., \& Ntoumanis, N. (2007). Development of the attitudes to moral decisionmaking in youth sport questionnaire. Psychology of Sport and Exercise, 8(3), 369-392. https://doi.org/10.1016/j.psychsport.2006.12.002

MEB. (2013). Çocuk Gelişimi ve Eğitimi, Ahlak Gelişimi. Retrieved from http://www.megep. meb.gov.tr/mte_program_modul/moduller_pdf/Ahlak\%20Geli\%C5\%9Fimi.pdf.3-20

Mouratidou, K., Chatzopoulos, D., \& Karamavrou, S. (2007). Moral development in sport context: Utopia or reality. Hellenic Journal of Psychology, 4(2), 163-184.

Murray, B. (1998). Does 'Emotional Intelligence' Matter In The Workplace? American Psychological Assocation, 29(7). https://doi.org/10.1037/e529992010-017

Mutlu, O. T., Şentürk, E. H., \& Zorba, E. (2014). Üniversite Öğrencisi Tenisçilerde Empatik Eğilim ve İletişim Becerisi. Special Issue on the Proceedings of the 3rd ISCS Conference SI(1), 129-137. https://doi.org/10.14486/IJSCS85

Özbek, M. (2005). The place and importance of empathy in human relations. Journal of Social Policy Conferences, 49.

Ponseti, F. J., Palou, P., Borràs, P. A., Vidal, J., Cantallops, J., Ortega, F., ... Garcia-Mas, A. (2012). El Cuestionario de Disposición al Engaño en el Deporte (CDED): Su aplicación a jóvenes deportistas. Revista de Psicología del Deporte, 21(1), 75-80.

Popescu, V., \& Masari, G.-A. (2011). Comparative Analysis of athletes' fair play attitude according to specific variables conditioned by sports training and competition. Procedia-Social and Behavioral Sciences, 12, 24-29. https://doi.org/10.1016/j.sbspro.2011. 02.006

Riess, H. (2017). The Science of Empathy. Journal of Patient Experience, 4(2), 74-77. https://doi.org/10.1177/2374373517699267

Rueckert, L., \& Naybar, N. (2008). Gender Differences in Empathy: The Role of the Right Hemisphere. Brain and Cognition, 67(2), 162-167. https://doi.org/10.1016/j.bandc.2008. 01.002

Sağın, A. E., \& Akbuğa, T. (2019). Lisanslı Spor Yapan Öğrencilerle Yapmayan Öğrencilerin Bazı Değişkenler Açısından Sosyal-Duygusal ve Ahlaki Gelişim Düzeyleri. Journal of Global Sport and Education Research, 2(1), 35-44.

Sezen-Balçikanli, G., \& Sezen, M. (2017). Professional Sports and Empathy: Relationship 
Between Professional Futsal Players' Tendency Toward Empathy and Fouls. Physical Culture and Sport. Studies and Research, 73(1), 27-35. https://doi.org/10.1515/pcssr-2017-0003

Shrout, M. R., Voelker, D. K., Munro, G. D., \& Kubitz, K. A. (2016). Associations Between Sport Participation, Goal and Sportspersonship Orientations, and Moral Reasoning. Ethics \& Behavior, 27(6), 502-518. https://doi.org/10.1080/10508422.2016.1233494

Singh, K. R., \& Mili, A. (2015). Study of Emotional Intelligence among Players of Individual, Dual and Team Sports. International Journal of Science and Research, 12(5), 1101-1106.

Soflu, G. H., Esfahani, N., \& Assadi, H. (2011). The Comparison of emotional intelligence and psychological skills and their relationship with experience among individual and Team athletes in superior league. Social and Behavioral Sciences, 30, 2394-2400. https://doi.org/ 10.1016/j.sbspro.2011.10.466

Topçu, Y. (2019). Farklı Statüdeki Lise Öğrencilerinin Spor Yapma Alışkanlıkları, Empatik Ĕgilim ve İletişim Becerilerinin İncelenmesi. T.C. Trabzon Üniversitesi Lisansüstü Eğitim Enstitüsü Beden Eğitimi ve Spor Anabilim Dalı, Trabzon.

Toussaint, L., \& Webb, J. R. (2005). Gender differences in the relationship between empathy and forgiveness. The Journal of Social Psychology, 145(6), 673-685. https://doi.org/10.3200/ SOCP.145.6.673-686

Tsai, E., \& Fung, L. (2005). Sportspersonship in youth basketball and volleyball players. Athletic Insight, 7(2), 37-46.

Tucker, L. W., \& Parks, J. B. (2001). Effects of gender and sport type on intercollegiate athletes' perceptions of the legitimacy of aggressive behaviors in sport. Sociology of Sport Journal, 18(4), 403-413. https://doi.org/10.1123/ssj.18.4.403

Turan, S. (2020). Okul sporlarına katılan ortaöğretim öğrencilerinin sporda ahlaktan uzaklaşma durumlarının bazı değişkenler açısından incelenmesi. Spor Eğitim Dergisi, 4(1), 8-19.

Turnage, B. F., Hong, Y. J., Stevenson, A. P., \& Edwards, B. (2012). Social work students" perceptions of themselves and others: Self-esteem, empathy, and forgiveness. Journal of Social Service Research, 38(1), 89-99. https://doi.org/10.1080/01488376.2011.610201

Wagnsson, S., Stenling, A., Gustafsson, H., \& Augustsson, C. (2016). Swedish youth football players' attitudes towards moral decision in sport as predicted by the parent-initiated motivational climate. Psychology of Sport and Exercise, 25, 110-114. https://doi.org/10.1016/ j.psychsport.2016.05.003

Yaffe, Y., Levental, O., Arey, D. L., \& Lev, A. (2021). Morality and Values in Sports Among Young Athletes: The Role of Sport Type and Parenting Styles-A Pilot Study. Frontiers in Psychology, 12, 618507. https://doi.org/10.3389/fpsyg.2021.618507

Yiğiter, K. (2008). Kocaeli ilinde görevli ilk ve orta öğretim kurumlarında çalışan beden eğitimi ve spor ögretmenlerinin empati becerilerinin incelenmesi (Master's thesis, Sakarya 
Üniversitesi).

Yücel, A. S., Atalay, A., \& Gürkan, A. (2015). Sporda Şiddet ve Saldırganlığı Etkileyen Unsurlar. Uluslararası Hakemli Psikiyatri ve Psikoloji Araştırmaları Dergisi, 2(2), 68-90.

\section{Copyright Disclaimer}

Copyright for this article is retained by the author(s), with first publication rights granted to the journal.

This is an open-access article distributed under the terms and conditions of the Creative Commons Attribution license (http://creativecommons.org/licenses/by/3.0/). 